ECOLOGICA, Vol. 28, No 104 (2021), 634-642

https://doi.org/10.18485/ecologica.2021.28.104.20

Originalni naučni rad

UDC: $628.16(497.11)$

\title{
Izbor strategije za implementaciju plutajućih ostrva u praksi
}

\section{Selection of a strategy for the implementation of floating islands in practice}

\author{
Nevena Čule ${ }^{*}$, Tanja Vujanov ${ }^{2}, Z_{\text {Zorica Sredojević }}{ }^{3}$, Mirjana Bojović ${ }^{4}$, \\ Marija Nešić ${ }^{5}$, Suzana Mitrović ${ }^{6}$, Ljiljana Brašanac-Bosanac ${ }^{7}$ \\ 1,6,7 Institut za šumarstvo, Kneza Višeslava 3, 11030 Beograd, Srbija / \\ Institute of forestry, Kneza Višeslava 3, 11030 Belgrade, Serbia \\ 2,4Univerzitet Educons, Fakultet ekološke poljoprivrede, Vojvode Putnika 87, 21208 Sremska Kamenica, Srbija / \\ Educons University, Faculty of Ecological Agriculture, Vojvode Putnika 87, 21208 Sremska Kamenica, Serbia \\ ${ }^{3}$ Univerzitet u Beogradu, Poljoprivredni fakultet, Nemanjina 6, 11080, Beograd, Srbija / \\ University of Belgrade, Faculty of Agriculture, Nemanjina 6, 11080, Belgrade, Serbia \\ 5Univerzitet u Beogradu, Šumarski fakultet, Kneza Višeslava 1, 11030 Beograd, Srbija / \\ University of Belgrade, Faculty of forestry, Kneza Višeslava 1, 11030 Belgrade, Serbia \\ ${ }^{*}$ Autor za prepisku / Corresponding author
}

Rad primljen / Received: 08.10.2021, Rad prihvaćen / Accepted: 06.11.2021.

Sažetak: Plutajuća ostrva su tehnologija za prečišćavanje voda koja ima ekološki, ekonomski i društveni značaj. U ovom radu su primenom SWOT analize određeni raspoloživi resursi i mogućnosti plutajućih ostrva prema pretnjama i šansama za uvođenje u standardnu infrastrukturu za tretman zagađenih voda. Zaključeno je da je plutajuća ostrva imaju multifunkcionalan značaj u predelu u kome se nalaze. Pored revitalizacije vodenih površina, ona dovode i do povećanja estetske vrednosti okoline, što može uticati na povećanje vrednosti nekretnina u blizini, privlačenje investitora, razvoj turizma, stvaranje prostora za rekreaciju i odmor stanovništva i finansiranje narednih ekoloških projekata. Najveća prepreka za implementaciju plutajućih ostrva je to što oni nisu prepoznati u zakonima i propisima Republike Srbije. Međutim, primenom odabrane optimalne strategije, koja se fokusira na interne snage biološkog sistema da bi što bolje iskoristila eksterne šanse za konstrukciju, postavljanje, primenu, monitoring i održavanje plutajućih ostrva omogućilo bi se brže prihvatanje ove tehnologije i njena primena u praksi.

Ključne reči: SWOT analiza, plutajuća ostrva, zagađenje vode, fitoremedijacija, revitalizacija, ekološki sistem.

\begin{abstract}
Floating islands are water treatment technology that has ecological, economic, and social significance. This study determines the available resources and possibilities of the floating islands according to the threats and chances for their introduction into the standard infrastructure for the treatment of polluted waters by applying the SWOT analysis. It was concluded that the floating islands have a multifunctional significance in the located landscape. In addition to the water revitalization, these biological systems increase the aesthetic value of the environment, and value of the nearby real estate, attract investors, improve tourism development, create space for recreation and leisure, and opportunities for financing future environmental projects. The biggest obstacle to the implementation of floating islands is that they are not recognized in the laws and regulations of the Republic of Serbia. However, the application of the selected optimal strategy, which focuses on the internal strengths of the biological system to make the best use of external opportunities for construction, installation, application, monitoring and maintenance of floating islands, can enable faster acceptance of this technology and its application in practice.
\end{abstract}

Keywords: SWOT analysis, floating islands, water pollution, phytoremediation, revitalization, ecological system.

\footnotetext{
10rcid.org/0000-0002-1846-989X, e-mail: nevena.cule@yahoo.com

2orcid.org/0000-0002-6175-2316, e-mail: tanjastanisin@gmail.com

3orcid.org/0000-0001-7224-1573, e-mail: zokas@agrif.bg.ac.rs

4orcid.org/0000-0002-5767-8221, e-mail:mimatopic@gmail.com

5orcid.org/0000-0001-6019-7683, e-mail: marija.nesic@sfb.bg.ac.rs

6orcid.org/0000-0003-1855-4418, e-mail: mitrovicsuzana79@gmail.com

7orcid.org/0000-0002-3324-674X, e-mail: brasanlj@yahoo.com
} 


\section{UVOD / INTRODUCTION}

U urbanim sredinama rečni tokovi i obale su zagađeni do te mere da se ne mogu koristiti ni za rekreaciju ni odmor usled neprijatnog mirisa i izgleda. Umesto da doprinose kvalitetu životne sredine i upotpunjuju sliku okolnog pejzaža, mali vodotoci često služe za prikupljanje otpadnih voda industrije i naselja, pa dodatno ugrožavaju vode u koje se ulivaju (Ocokoljić et al., 2009). Savremeno, ekološki svesno društvo postavlja zahteve na koje konvencionalna postrojenja za prečišćavanje vode ne mogu da odgovore, usled neusklađenosti sa principima konzervacije vode. Rešenja u inženjerstvu koja su po ugledu na prirodu, sa razumevanjem i poštovanjem principa zaštite životne sredine omogućavaju održivi razvoj. Plutajuća ostrva za prečišćavanje zagađenih voda su živi sistemi u kojima se tretman voda vrši zahvaljujući prirodnim procesima. Imitirajući procese samoprečišćavanja, koji se inače javljaju u akvatičnim ekosistemima, omogućavaju uklanjanje različitih kategorija polutanata, uz racionalno korišćenje prirodnih resursa i nesmetano kruženje materije i energije u prirodi po principima bioremedijacije, odnosno rizofiltracije (Benvenuti et al., 2018; Chen et al., 2017; Dodkins \& Mendzil, 2014; Jones et al., 2017). Kao efikasan način prečišćavanja i ekološkog obnavljanja, ovaj biološki sistem ima istoriju korišćenja dugu skoro 40 godina i primenu na rekama, jezerima i postojećim rezervoarima (Yang et al., 2021). Plutajuća ostrva se sastoje od nosača, koji omogućava plutanje ostrva na površini vode, supstrata i akvatični i terestričnih biljaka sa združenim mikroorganizmima (Chance et al., 2019; Cule et al., 2021; Sharma et al., 2021). U ruralnim područjima, neplanski građenim i nehigijenskim naseljima postavljanjem ovih bioloških sistema u okviru reka, jezera ili bara mogu se otkloniti posledice nastale neplanskom gradnjom, na primer usled nedostatka vodovodnog i kanalizacionog sistema. Uklanjanjem različitih polutanata iz zagađenih voda sprečila bi se pojava određenih bolesti, koje uzrokuju patogeni mikroorganizmi prisutni u otpadnim vodama. Prema dosadašnjim istraživanjima, autori su plutajuća ostrva svrstavali u investicije, koje nemaju samo ekološki efekat, nego donose i prihode, omogućavaju održivo korišćenje prirodnih resursa, podižu kvalitet životne sredine, pozitivno utiču na socio-ekonomski i privredni razvoj društva (Davis, 1995; Prasad \& De Oliveira Freitas, 2003).

U ovom radu su SWOT analizom određeni raspoloživi resursi i mogućnosti plutajućih ostrva prema pretnjama i šansama za njihovo uvođenje u standardnu infrastrukturu za tretman otpadnih i zagađenih voda. Takođe, predložena je optimalna stra- tegija za bržu implementaciju ovih bioloških sistema u praksi.

\section{MATERIJALI I METODE / MATERIALS AND METHODS}

$S$ obzirom na multifunkcionalnu ulogu i različite efekte, koji se postižu korišćenjem plutajućih ostrva za prečišćavanje otpadnih i zagađenih voda, SWOT analizom su sagledane snage, slabosti, mogućnosti i potencijalni rizici implementacije plutajućih ostrva u praksi, kao i mogućnost njihove održivosti. Na osnovu analize SWOT matrice odnosno upoređivanja snaga i slabosti sa šansama i pretnjama odabrana je optimalna strategija za konstrukciju, postavljanje, primenu, monitoring i održavanje plutajućih ostrva u praksi.

\section{REZULTATI I DISKUSIJA / RESULTS AND DISCUSSION}

$\mathrm{Na}$ osnovu rezultata SWOT analize, prikazanih u tabeli 1, procenjeni su potencijali mogućeg projekta postavljanja plutajućih ostrva, rizici u toku njegove realizacije, kao i mogućnosti njegove održivosti.

Visoka efikasnost bioloških sistema u uklanjanju širokog spektra polutanata iz voda je jedna od najznačajnijih snaga plutajućih ostrva. Različiti autori navode da se efikasnost uklanjanja kreće: 52-96\% za organske polutante izražene kroz BPK5, 23-96\% za suspendovane materije, 6-99\% za N, 7-95\% za $\mathrm{P}, 75-99 \%$ za Cd, $40-96 \%$ za Cu, 0-86\% za Pb, 49$88 \%$ za $\mathrm{Ni}, 33-96 \%$ za $\mathrm{Zn}$ i $90-99 \%$ za različite patogene mikroorganizme (Chance \& White, 2018; Cule et al., 2021; Davis, 1995; Pavlineri et al., 2017; Van de Moortel et al., 2010; White \& Cousins, 2013; Xian et al., 2010; Yang et al., 2008; Zhou \& Wang, 2010). Ništa manje važna činjenica je i da su konstrukcija i izgradnja plutajućih ostrva i njihovo povezivanje u sistem vrlo jednostavni. Ovi biološki sistemi se sastoje od plastičnog nosača, supstrata i živih organizama (biljke, alge, mikroorganizmi i dr.), koji prirodnim putem vraćaju ekološki integritet rekama opterećenim različitim polutantima (Benvenuti et al., 2018; Čule et al., 2017; Sharma et al., 2021; Stewart et al., 2008). Takođe, troškovi konstrukcije, rada i održavanja plutajućih ostrva su mnogo manji u poređenju sa istim troškovima konvencionalnih postrojenja, pa čak i drugih alternativnih metoda za tretman vode, što uglavnom proističe iz lakoće njihove konstrukcije i skromnih potreba za održavanjem (Solano et al., 2004). Postavljanje biološkog sistema na terenu je brzo i dnevno je moguće postaviti 50 100 plutajućih ostrva. Troškovi održavanja su vrlo niski, naročito ako se monitoring obavlja redovno, pa je eventualne greške ili oštećenja osnovnih kompo- 
nenti lako ukloniti po njihovoj pojavi (Hammer, 1989). Na niske troškove rada ukazuje i činjenica da za svoj rad troše isključivo sunčevu energiju, koju biljke kori- ste za fotosintezu (Shutes, 2001; Stottmeister et al., 2003).

Tabela 1. SWOT analiza primene plutajućih ostrva

Table 1. SWOT analysis of the application of floating islands

\begin{tabular}{|c|c|}
\hline & \\
\hline $\begin{array}{l}\text { - } \text { efikasna, ekološki opravdana i ekonomski isplativa } \\
\text { - } \quad \text { tehnički jednostavna i tehnološki lako izvodljiva } \\
\text { investicija za primenu u praksi } \\
\text { - } \text { mogućnost dimenzionisanja za različite slučajeve } \\
\text { - } \quad \text { nrilagodljivost konfiguraciji rečnih obala i promeni } \\
\text { nivoa reke } \\
\text { - zaštita obala reke od erozije } \\
\text { - mogućnost korišćenja terestričnih i akvatičnih biljaka } \\
\text { - } \text { prečišćavanje vode na prirodan način } \\
\text { - } \text { tehnogućnost tretmana velikih količina vode } \\
\text { - } \text { količinom otpada } \\
\text { - mogućnost korišćenja dobijene nadzemne biomase } \\
\text { - uklapanje u okolini pejzaž } \\
\text { - povećanje estetske vrednosti okolnog pejzaža } \\
\text { - podstrek za različita naučna istraživanja i edukaciju }\end{array}$ & $\begin{array}{l}\text { - } \quad \text { nova tehnologija i rizik od neizvesnosti } \\
\text { - } \quad \text { institucionalno nije regulisana nadležnost } \\
\text { organa za postavljanje plutajućih ostrva } \\
\text { - } \quad \text { izostanak očekivanih rezultata, dobijenih u } \\
\text { laboratorijskim uslovima, u praksi } \\
\text { - } \quad \text { nepredviđenost ovih investicija zakonom, } \\
\text { neuređenost fondova za finansiraje, } \\
\text { kvantitativno izražavanje efekata njihovog } \\
\text { korišćenja i na koji način mogu da se prikupljaju } \\
\text { nadoknade od njihovih potencijalnih korisnika je } \\
\text { otežano } \\
\text { - } \quad \text { konstrukcioni i operativni kriterijumi nisu } \\
\text { precizni } \\
\text { - efikasnost prečišćavanja može da varira u } \\
\text { odnosu na godišnje doba } \\
\text { - } \quad \text { koristijivost bioloških komponenti } \\
\text { srednjom koncentracijom polutanata }\end{array}$ \\
\hline & \\
\hline 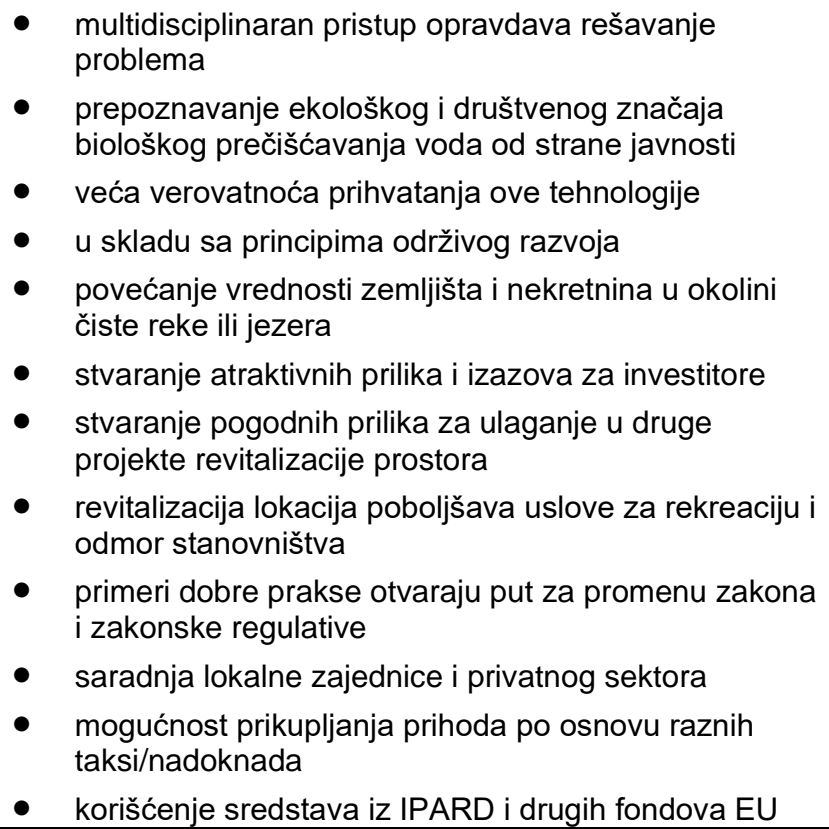 & 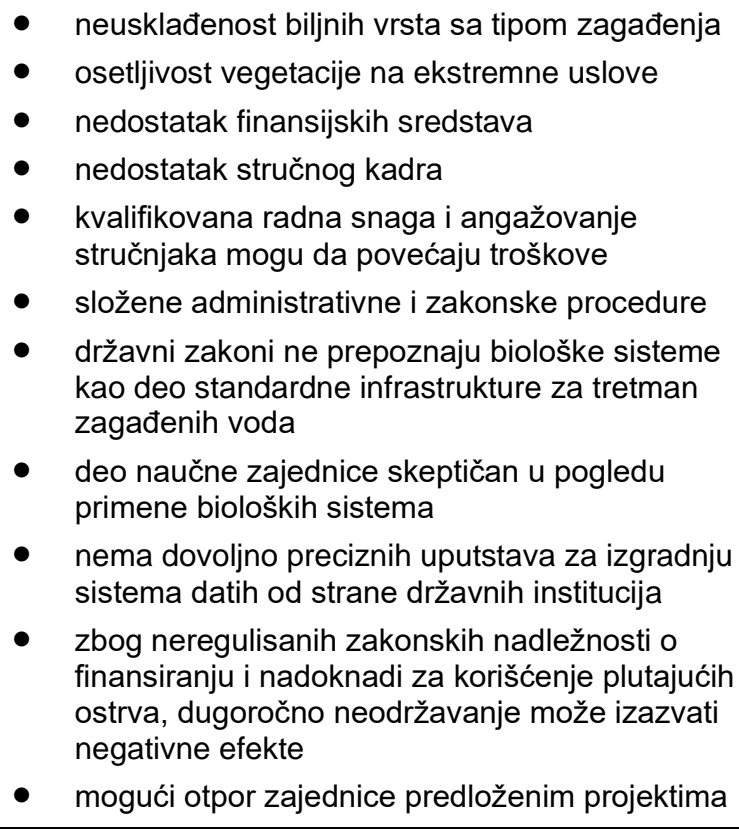 \\
\hline
\end{tabular}

Sistem plutajućih ostrva se sastoji od više povezanih plutajućih ostrva, što ukazuje na mogućnost njegovog dimenzionisanja za različite slučajeve, kao i prilagođavanje različitim konfiguracijama rečnih obala. Zahvaljujući tome, biološki sistem je prilagođen mogućim promenama nivoa vode u reci, ne re- meti stalan vodeni tok, a omogućava zaštitu neuređenih obala reke od erozije. Još jedna od važnih snaga plutajućih ostrva je i mogućnost korišćenja terestričnih i akvatičnih biljaka u procesu prečišćavanja. Ovo je značajno, jer terestrične biljke generalno uklanjaju veće količine polutanata od akva- 
tičnih biljaka (Ansari et al., 2020; Dushenkov et al., 1995) i pri tome imaju mogućnost stvaranja veće količine biomase (Buscaroli, 2017; Dushenkov i Kapulnik, 2000). Biološki sistemi za prečišćavanje otpadnih voda predstavljaju veštački stvorene, konstruisane, akvatične ekosisteme, koji zahvaljujući simbiotičkim odnosima između biljaka, mikroorganizama, algi, podloge i vode, imaju sposobnost da uklanjaju organske i mineralne materije, patogene mikroorganizme, teške metale i druge polutante iz otpadnih voda (Chen et al., 2017; Davis, 1995; Prasad \& de Oliveira Freitas, 2003; Stottmeister et al., 2003; Yeh et al., 2015). Zagađenje iz alternativnih sistema jednostavno ne postoji, a ukoliko se slučajno i pojavi to je znak njihove loše konstrukcije (Shutes, 2001). Kao jedna od prednosti bioloških sistema se navodi i to da je ovo tehnologija koja ne stvara nusprodukt, koji bi mogao da vrši negativan uticaj na životnu sredinu. Ovo je naročito izraženo ako se plutajuća ostrva koriste za tretman komunalnih otpadnih voda, u čijem sastavu preovlađuje zagađenje koje potiče od organskih materija i ukoliko je kao supstrat korišćen kokosov treset i drugi prirodni materijali. Kombinacijom procesa evaporacije, isušivanja podloge i usvajanja hranljivih materija od strane biljaka, podloga može da se pretvori u supstrat sličan humusu, koji može da se koristi kao đubrivo (Davis, 1995). Ukoliko se biološki sistem koristio za eliminisanje teških metala i drugih toksičnih elemenata onda se pre misli na tehnologiju sa redukovanom količinom sekundarnog otpada. Na kraju procesa rizofiltracije, teški metali su u biljkama uglavnom locirani u korenovom sistemu, jer translokacija u nadzemne delove izostaje (Cule et al., 2021; Cule et al., 2016). Na ovaj način količina biljnog otpada za odlaganje je značajno smanjena. Pokošena nadzemna biomasa može da se koristi u različite energetske svrhe, a njenom prodajom je moguće ostvariti novčanu dobit. Neki od metali mogu da budu ponovo ekstrahovani iz pepela uklonjenih biljaka pomoću različitih kiselina, što još dodatno smanjuje generisanje opasnog otpada i omogućava brže stvaranje profita (Ali et al., 2020).

Pored osnovne funkcije, uklanjanja polutanata, biljke u sistemu plutajućih ostrva, imaju i druge funkcije, koje su značajne na pojedinim mestima prečišćavanja. Slično kao i u prirodnim akvatičnim ekosistemima, vegetacija formira stanište za različite životinjske vrste. Ovo je naročito značajno u degradiranim predelima sa osiromašenim biljnim i životinjskim diverzitetom (Sharma et al., 2021). U ovakvim predelima, estetska vrednost vegetacije predstavlja dopunu sveukupnom ambijentu (Yeh et al., 2015). Zahvaljujući svojoj konstrukciji i osnovnim komponentama biološki sistemi mogu potpuno da se uklope u okolni pejzaž. Takođe, sistemi plutajućih ostrva, predstavljaju pogodna mesta za podstrek naučne zajednice za sprovođenje različitih istraživanja. Oni mogu da omoguće i edukaciju ljudi u skladu za održivim razvojem, kroz promovisanje važnosti očuvanja životne sredine i konzervacije voda (Calheiros et al., 2020).

Kao osnovne slabosti, koje predstavljaju ograničenje za šire korišćenje plutajućih ostrva, u literaturi se navode činjenice da je ovo nova tehnologija, koja sa sobom nosi različite rizike, da konstrukcioni i operativni kriterijumi još uvek nisu dovoljno precizni i da se često razlikuju od slučaja do slučaja, kao i da ne postoji zakonska podrška od državnih institucija i organa za njihovo uvođenje u praksu (Benvenuti et al., 2018; Davis, 1995; Pavlineri et al., 2017; Solano et al., 2004). Pri proceni mogućnosti bioloških sistema treba imati na umu i da rezultati laboratorijskih eksperimenata ili istraživanja u staklenicima ne moraju uvek da budu sa uspehom preneseni u praksu. S obzirom da sistemi plutajućih ostrva, kako i drugi biološki sistemi za tretman voda, još uvek nisu prepoznati u našim zakonima, institucionalno nije regulisana nadležnost organa za postavljanje ostrva na odgovarajućim lokacijama. Takođe, zakonski nije uređeno ni iz kojih fondova mogu da se finansiraju ovakve investicije i na koji način mogu da se prikupljaju nadoknade od njihovih potencijalnih korisnika. Kada se govori o pouzdanosti alternativnih postrojenja obično se postavlja pitanje njihovog rada tokom zime. Biološki sistemi mogu da prečišćavaju vodu čak i pri niskim temperaturama, ali sa nešto slabijim intenzitetom uklanjanja polutanata (Jenssen \& Vatn, 1996; Obarska-Pempkowiak, 1996; Shutes, 2001). Ovo je svakako prihvatljivo u slučajevima kada je variranje u kvalitetu vode dozvoljeno tokom godine. Međutim, tamo gde je neophodno da prečišćena voda zadovolji stroge standarde tokom cele godine variranje efikasnosti predstavlja značajnu slabost. Osetljivost bioloških komponenti sistema na različite toksične materije, takođe može da se shvati kao ograničenje plutajućih ostrva. Zato se u literaturi često navodi da su rizofiltracioni sistemi pogodni za tretman velikih količina voda koje sadrže niske, ali značajne koncentracije teških metala i drugih toksičnih materija (Ensley, 2000; Prasad \& de Oliveira Freitas, 2003). I pored toga, iznenadno oštećenje ili propadanje vegetacije plutajućih ostrva, usled nedozvoljenog izlivanja zagađene vode sa koncentracijom polutanata iznad maksimalno dozvoljenih vrednosti, napada štetočina ili bolesti i ekstremnih vremenskih uslova predstavlja ozbiljnu slabost. Kao slabost tehnologije može da se shvati $i$ to što biljke (naročito terestrične) najčešće moraju da se zasnivaju i gaje 
na nekom drugom mestu, a da se zatim presađuju na plutajuća ostrva.

Dalji razvoj svih alternativnih metoda za prečišćavanje voda mora da se kreće u pravcu njihove komercijalizacije. Multidisciplinaran pristup rešavanju problema je značajna šansa za plutajuća ostrva, jer kombinovanje saznanja različitih naučnih disciplina može da dovede do prevazilaženja različitih slabosti i pretnji, koje kao unutrašnji i spoljašnji faktori utiču na njegovu primenu u praksi. Plutajuća ostrva su u skladu sa principima održivog razvoja, jer omogućava racionalno korišćenje prirodnih resursa i simulaciju kruženja materije u prirodi. Ova činjenica predstavlja još jednu šansu za uvođenje plutajućih ostrva u standardnu praksu za oporavak zagađenih reka i vodenih površina, jer oni mogu da pomognu u prepoznavanju ekološkog i društvenog značaja biološkog prečišćavanja voda od strane javnosti. Ovo ima još veći značaj ako se zna da je veća verovatnoća prihvatanja ove tehnologije od strane javnosti i nadležnih organa u odnosu na druge alternativne tehnologije (Dodkins \& Mendzil, 2014). Sistemi plutajućih ostrva mogu da budu značajno sredstvo za povećanje vrednosti zemljišta i nekretnina, koje se nalaze u blizini reke, kroz njenu revitalizaciju i povećanje estetske vrednosti okoline. Ovo će dalje stvoriti atraktivne prilike za privlačenje investitora, kako za finansiranje narednih projekata postavljanja plutajućih ostrva tako i za ulaganje u druge ekološke projekte revitalizacije prostora. Takođe, oni mogu da pomognu u povećanju potencijala okoline za razvoj turizma i stvaranju prostora za rekreaciju i odmor stanovništva (Nakamura \& Mueller, 2008), kroz revitalizaciju lokacija, koje se nalaze u blizini reke ili vodene površine, a koje su označene kako prioritetne lokacije sa velikim potencijalom za razvoj ovih delatnosti. Pri primeni nove tehnologije u praksi, iskustvo je veoma važno, a primeri dobre prakse mogu da otvore ne samo put za finansiranje izgradnje novih sistema plutajućih ostrva već i za promenu zakona i zakonske regulative u pogledu korišćenja različitih bioloških sistema kao dela standardne infrastrukture za tretman zagađenih voda. Realizacija projekata izgradnje sistema plutajućih ostrva stvara povoljne prilike za saradnju lokalne zajednice i privatnog sektora. Ovakva saradnja pri realizaciji ekoloških projekata je vrlo značajna, jer je na ovaj način je izvedena podela rizika, finansiranja i dobiti, što je veoma značajno pri realizaciji ekoloških projekata (IonescuHeroiu, 2010). Kroz različite oblike podsticaja, finansijske ili nefinansijske prirode, lokalne vlasti mogu da privuku na primer najveće zagađivače u okviru sliva da finansiraju izgradnju sistema plutajućih ostrva i da na taj način ublaže posledice svog nesaves- nog ispuštanja neprečišćene otpadne vode direktno u reku.

Sistemi pultajućih ostrva mogu da imaju veliki značaj u ruralnim područjima, neplanski građenim i nehigijenskim naseljima, jer mogu da pomognu da se otklone propusti nastali neplanskom gradnjom, kao što je nedostatak vodovodnog i kanalizacionog sistema. Kroz uklanjanje različitih kategorija polutanata poboljšali bi se sanitarno - higijenskih uslovi, sprečila bi se potencijalna pojava različitih bolesti i poboljšale bi se estetske vrednosti ovih naselja. $\mathrm{Na}$ osnovu navedenog, moguće je zaključiti da različiti EU fondovi, a prvenstveno IPA fondovi mogu da posluže kao važni elementi za implementaciju projekata konstrukcije i postavljanja sistema plutajućih ostrva. Značajna sredstva za realizaciju projekata bi mogla da se dobiju i iz državnog budžeta na osnovu različitih naknada i taksi, koji se posredstvom Fondova za vode Republike Srbije ili autonomne pokrajine Vojvodine, prikupljaju na osnovu korišćenja vode kao prirodnog resursa ili kazni za nanošenje štete životnoj sredini kroz na primer ispuštanje nedovoljno prečišćene vode iz procesa proizvodnje direktno u reku.

Posle svih istaknutih prednosti (snaga i šansi) plutajućih ostrva nameću se pitanja zašto ovi biološki sistemi još uvek nemaju veću primenu u praksi, zašto ih državni zakoni u većini zemalja ne prepoznaju kao deo standardne infrastrukture za tretman zagađenih voda i zašto je deo naučne zajednice i dalje skeptičan u pogledu njihovog korišćenja. Glavna pretnja za realizaciju svih projekata, pa tako i projekta izgradnje sistema plutajućih ostrva je često nedostatak finansijskih sredstava za podršku i investiranje u ekološke projekte. Problem predstavlja i nedostatak stručnog kadra odnosno inženjera, koji mogu da projektuju i konstruišu ova postrojenja. Angažovanje kvalifikovane radne snage i stručnjaka za monitoring i održavanje Sistema, kao i složene administrativne i zakonske procedure za dobijanje različitih neophodnih dozvola mogu da utiču na povećanje troškova celokupnog projekta. Neregulisana zakonska nadležnost o finansiranju i nadoknadi za korišćenje plutajućih ostrva može da dovede do dugoročnog neodržavanja plutajućih ostrva, što može da izazove različite negativne efekte. Ukoliko u okviru biološkog sistema nisu sprovedene pravilne mere monitoringa i održavanja, efikasnost sistema može da bude ugrožena (Čule et al., 2017). Još jedna od potencijalnih pretnji za uvođenje plutajućih ostrva, pa i drugih bioloških sistema, u standardnu praksu prečišćavanja je i ta što nema dovoljno preciznih uputstava ili dokumenata za izgradnju sistema datih od strane državnih institucija (BrašanacBosanac et al., 2020). Otpor društva ili negativan 
stav zajednice može da se javi pri realizaciji bilo kog projekta. Čak i ekološki projekti, za koje se pretpostavlja da će doneti isključivo boljitak društvu, mogu da se nađu pred ovakvom preprekom. Ozbiljna pretnja je i neusklađenost vrsta bioloških kultura sa tipom otpadnih voda i opasnost da rešenje ne daje očekivane efekte. Diverzitet biljnih vrsta pogodnih za korišćenje u fitoremedijaciji voda zagađenih teškim metalima i drugim polutantima je veliki (Lone et al., 2008). Odabir prave vrste za dati slučaj odnosno za postojeće zagađenje još uvek predstavlja jedan od glavnih problema (Cule et al., 2021; Kadlec \& Wallace, 2008). Nadovezujući se na ovu pretnju i potencijalna nemogućnost biljnog sklopa na plutajućim ostrvima da odoli iznenadnim ekstremnim klimat- skim faktorima može da predstavlja ozbiljnu prepreku za uspešnost celokupnog tretmana otpadnih voda (Chen \& Costa, 2020).

$\mathrm{U}$ tabeli 2 prikazane su potencijalne strategije, koje mogu da pomognu u prevazilaženju navedenih problema pri realizaciji projekta izgradnje predloženog sistema plutajućih ostrva i njegovu primenu u praksi. Na osnovu analize potencijalnih strategija, jasno je da je S-O (snage-šanse) najbolja strategija, koja bi mogla da omogući brže prihvatanje projekata sistema plutajući ostrva i njihovu primenu u praksi. Svaka nova tehnologija, koja može da prepozna svoje šanse na tržištu i da ih pretvori u svoje snage se smatra ostvarenom i uspešnom tehnologijom.

Tabela 2. Potencijalne strategije za implementaciju plutajućih ostrva u praksu

Table 2. Potential strategies for the implementation of floating island in practice

\begin{tabular}{|l|c|c|}
\hline & SNAGE (S) & SLABOSTI (W) \\
\hline ŠANSE (O) & $\begin{array}{c}\text { S-O strategija se fokusira na interne } \\
\text { snage biološkog sistema za što bolje } \\
\text { iskorišćavanje eksternih šansi }\end{array}$ & $\begin{array}{c}\text { W-O strategija teži da ukloni navedene } \\
\text { interne slabosti biološkog sistema kako bi } \\
\text { iskoristila njegove navedene eksterne šanse }\end{array}$ \\
\hline PRETNJE (T) & $\begin{array}{c}\text { S-T strategija koristi navedene } \\
\text { interne snage biološkog sistema } \\
\text { kako bi umanjila njegove navedene } \\
\text { eksterne pretnje }\end{array}$ & $\begin{array}{c}\text { W-T defanzivna strategija se koristi u svrhu } \\
\text { smanjenja interne slabosti biološkog sistema } \\
\text { i izbegavanja eksternih pretnji }\end{array}$ \\
\hline
\end{tabular}

Od svih nabrojanih šansi u okviru SWOT analize pretpostavlja se da je prevođenje šanse opisane kao primeri dobre prakse, koji mogu da privuku investitore i omoguće promenu zakona i zakonske regulative, u stvarnu snagu biološkog sistema najznačajnije. To se na primer može postići, ukoliko se troškovi prvih projekata značajno smanje, kroz biranje rečnih tokova sa uređenim obalama, zatim onih $u$ kojima su vrste zagađenja unapred poznate i u okviru kojih je uspostavljen redovan monitoring kvaliteta voda od strane lokalne vlasti ili države. Dalje, prve sisteme plutajućih ostrva treba postavljati na značajnim lokacijama za grad i njegove stanovnike uz napomenu da je poželjno birati vode sa niskim do umerenim koncentracijama zagađujućih materija. Nakon izvođenja prvih projekata, demonstriranja njihove efikasnosti u praksi i ostvarivanja novčane dobiti, koja može da se iskoristi za realizaciju narednih projekata, stvoriće se povoljna atmosfera za prihvatanje ove tehnologije od strane javnosti i nadležnih organa. Kao što je već napomenuto, reke sa obnovljenim ekološkim integritetom povećavaju vrednost zemljišta i nekretnina u svojoj okolini i stvaranju atraktivne prilike i izazove za investitore. I na kraju, angažovanje svih interesnih grupa, pri čemu se misli na građane, potencijalne investitore, lokalnu vlast $\mathrm{i}$ nadležne državne institucije, može da dovede od promene zakona i zakonske regulative i prepozna- vanja plutajućih ostrva kao dela standardne infrastrukture za tretman zagađenih voda.

Kada se šanse Sistema pretvore u njegove realne snage, moguće je primeniti i S-T (snage-pretnje) strategiju, kako bi se umanjile ili eliminisale eksterne pretnje za uvođenje plutajućih ostrva u praksu. Novonastala snaga biološkog sistema, primeri dobre prakse, može da pomogne u prevazilaženju problema nedostatka materijalnih sredstava. lako je ovo velika prepreka, koja može da obeshrabri i najvatrenije zagovornike zaštite životne sredine, nedostatak novca u državnim fondovima za zaštitu životne sredine je moguće nadomestiti dobijanjem sredstava iz međunarodnih fondova, organizacija i finansijskih institucija kao što je Svetska banka, za uspešne ekološke projekte od velikog značaja (Ionescu-Heroiu, 2010).

\section{ZAKLJUČAK / CONCLUSION}

$\mathrm{Na}$ osnovu rezultata SWOT analize može da se potvrdi da su plutajuća ostrva ekološki opravdana tehnologija, koja uz dostizanje ekološkog optimuma omogućava održivost prirodnih resursa. Zahvaljujući ustaljenim prirodnim procesima, radom mikroorganizama, biljaka i supstrata, bez upotrebe različitih hemijskih materija i dodatnih izvora energije ovi biološki sistemi mogu da uklanjaju sa visokom efikasnošću širok spektar polutanata iz zagađenih i ot- 
padnih voda. Pri tome oni stvaraju redukovan sadržaj otpada, koji može da posluži kao sirovina za druge tehnologije i da na taj način omogući stvaranje dodatnog profita. Plutajuća ostrva takođe mogu da omoguće reklamaciju i ponovno korišćenje voda, hranljivih materija i različitih bioloških resursa, što ukazuje ne samo na njegovu ekološku pogodnost, već i na njegov sklad sa osnovnim principima konzervacije voda i zahtevima, koje proklamuju različite EU direktive $u$ oblastima zaštite životne sredine $i$ voda. Implementacijom plutajućih ostrva moguće je ostvariti revitalizaciju reke, ne samo u smislu prečišćavanja njene zagađene vode, već i obnavljanja njenog nekadašnjeg biodiverziteta kroz povratak biljnih i životinjskih vrsta, koje su vremenom nestale zbog pogoršanih ekoloških uslova. Najveća prepreka za implementaciju projekata vezanih za korišćenje plutajućih ostrva, pa i drugih alternativnih bioloških sistema za prečišćavanje zagađenih i otpadnih voda je to što oni nisu prepoznati u zakonima koji regulišu oblasti zaštite životne sredine, zaštite prirode, vode i drugim relevantnim propisima Republike Srbije. Pretpostavlja se da je razlog za to što je ovo relativno nova tehnologija o kojoj još uvek nema dovoljno podataka, kao i već napomenuta činjenica da se njihova konstrukcija i efikasnost razlikuju od slučaja do slučaja, tako da je nemoguće izvući jedinstveni zaključak. Međutim, kao državni normativi u pogledu kvaliteta voda postaju sve stroži, zbog usklađivanja sa različitim EU direktivama, a ekološka svest društva postaje sve izraženija, tehnologije bazirane na prirodnim resursima, koje nude efikasno $i$ isplativo rešenje za tretman zagađenih $i$ otpadnih voda imaće sve veći značaj u praksi. Realizacijom projekata na osnovu znanja stečenog iz primera dobre prakse osposobiće se novi stručnjaci i kvalifikovana radna snaga, koji mogu da projektuju, konstruišu i prate rad ovih bioloških sistema. Na ovaj način, doći će i do preciznih uputstava, konstrukcionih i operativnih kriterijuma, tako da će nadležne državne institucije biti u prilici da ponude zvanična dokumenta za izgradnju sistema plutajućih ostrva. Uključivanje naučne zajednice i javnosti, na početku realizacije projekta, omogućiće ovim interesnim grupama lako sagledavanje aktualnosti i značaja plutajućih ostrva i na taj način ublažiće njihov potencijalni otpor korišćenju biljaka za prečišćavanje zagađenih voda.

\section{LITERATURA / REFERENCES}

[1] Ali, S., Abbas, Z., Rizwan, M., Zaheer, I.E., Yavaş, I., Ünay, A., Abdel-DAIM, M.M., Bin-Jumah, M., Hasanuzzaman, M., Kalderis, D. (2020). Application of Floating Aquatic Plants in Phytoremediation of Heavy Metals Polluted Water: A Review, Sustainability, 12(5), 1927. doi:10.3390/su12051927

[2] Ansari, A.A., Naeem, M., Gill, S.S., Al Zuaibr, F.M. (2020.) Phytoremediation of contaminated waters: An eco-friendly technology based on aquatic macrophytes application, Egypt. J. Aquat. Res., 46(4), 371-376.

[3] Benvenuti, T., Hamerski, F., Giacobbo, A., Bernardes, A.M., Zoppas-Ferreira, J., Rodrigues, M.A. (2018). Constructed floating wetland for the treatment of domestic sewage: a real-scale study, J. Environ. Chem. Eng., 6(5), 5706-5711.

[4] Brašanac-Bosanac, L., Čule, N., Lučić, A., Veselinović, M., Mitrović, S. (2020). Guidelines for the introduction of biological systems for revitalization of polluted water and wastewater treatment in strategic documents in Serbia, Sustainable Forestry, 81-82, 149-157.

[5] Buscaroli, A. (2017). An overview of indexes to evaluate terrestrial plants for phytoremediation purposes (Review), Ecol. Indic. 82, 367-380.

[6] Calheiros, C.S.C., Carecho, J., Tomasino, M.P., Almeida, C.M.R., Mucha, A.P. (2020). Floating Wetland Islands Implementation and Biodiversity Assessment in a Port Marina, Water, 12(11), 3273.

[7] Chance, L.M.G., Van Brunt, S.C., Majsztrik, J.C., White, S.A. (2019). Short- and long-term dynamics of nutrient removal in floating treatment wetlands, Water Res., 159, 153-163.

[8] Chance, L.M.G., White, S.A. (2018). Aeration and plant coverage influence floating treatment wetland remediation efficacy, Ecol. Eng.,122, 62-68.

[9] Chen, C., Zhao, T., Liu, R., Luo, L. (2017). Performance of five plant species in removal of nitrogen and phosphorus from an experimental phytoremediation system in the Ningxia irrigation area, Environ. Monit. Assess., 189(10), 1-13.

[10] Chen, Z., Costa, O.S., Jr. (2020). Artificial Floating Island System as a Sustainable Solution for Addressing Nutrient Pollution and Harmful Algal Blooms (HABs) in Ohio. American Geophysical Union, Fall Meeting 2020, abstract \#H116-0004.

[11] Cule, N., Lucic, A., Nesic, M., Veselinovic, M., Mitrovic, S., Sredojevic, Z., Brasanac-Bosanac, L. (2021). Accumulation of chromium and nickel by Canna indica and decorative macrophytes grown in floating treatment wetland, Fresenius Environ. Bull., 30(6 B), 7881-7890.

[12] Cule, N., Vilotic, D., Nesic, M., Veselinovic, M., Drazic, D., Mitovic, S. (2016). Phytoremediation potential of Canna indica L. in water contaminated with lead, Fresenius Environ. Bull., 25(11), 3728-3733. 
[13] Čule, N., Lučić, A., Dražić, D., Popović, V., Veselinović, M., Brašanac-Bosanac, L., Mitrović, S. (2017). Construction of floating treatment wetlands for remediation of polluted waters, Sustainable Forestry, (75-76), 1-12.

[14] Davis, L. (1995). A handbook of constructed wetlands: A guide to creating wetlands for: agricultural wastewater, domestic wastewater, coal mine drainage, stormwater. In the Mid-Atlantic Region. Vol.1: General considerations. USDA Natural Resources Conservation Service.

[15] Dodkins, I., Mendzil, A. (2014). Enterprise Assist: Floating Treatment Wetlands: Treatment efficiency and potential benefits of activated carbon. Sustainable Expansion of the Applied Coastal and Marine Sectors (SEACAMS), Swansea University, Swansea, Wales, p. 44.

[16] Dushenkov, S., Kapulnik, Y. (2000). Phytofiltration of Metals, in: Raskin, I., Ensley, D.B. (Eds.), Phytoremediation of toxic metals: using plants to clean up the environment. John Wiley and Sons, Inc, New York, pp. 89-106.

[17] Dushenkov, V., Kumar, P.B.A.N., Motto, H., Raskin, I. (1995). Rhizofiltration: The Use of Plants to Remove Heavy Metals from Aqueous Streams, Environ. Sci. Technol., 29(5), pp. 12391245.

[18] Ensley, D.B. (2000). Rationale for use of phytoremediation, in: Raskin, I., Ensley, D.B. (Eds.), Phytoremediation of toxic metals: using plants to clean up the environment. John Wiley and Sons, Inc, New York, pp. 3-12.

[19] Hammer, D.A. (1989). Constructed Wetlands for Wastewater Treatment: Municipal, Industrial and Agricultural. CRC Press, Taylor \& Francis, Boca Raton.

[20] lonescu-Heroiu, M. (2010). The management of brownfields redevelopment: $A$ guidance note. The World Bank.

[21] Jenssen, F.D., Vatn, A. (1996). Ecologically sound wastewater treatment: Concepts and implementation, in: Etnier, C., Guterstam, B. (Eds.), Ecological Engineering for Wastewater Treatment. CRC Press, Boca Raton, pp. 305-320.

[22] Jones, T.G., Willis, N., Gough, R., Freeman, C. (2017). An experimental use of floating treatment wetlands (FTWs) to reduce phytoplankton growth in freshwaters, Ecol. Eng., 99, 316-323.

[23] Kadlec, R.H., Wallace, S. (2008). Treatment wetlands, 2nd ed. Taylor \& Francis Group, CRC press, Boca Raton.

[24] Lone, M.I., He, Z.-I., Stoffella, P.J., Yang, X.-E. (2008). Phytoremediation of heavy metal polluted soils and water: progresses and perspectives, $J$. Zhejiang Univ. Sci. B., 9(3), 210-220.

[25] Nakamura, K., Mueller, G. (2008). Review of the Performance of the Artificial Floating Island as a Restoration Tool for Aquatic Environments, in: World Environmental and Water Resources Congress 2008. pp. 1-10.

[26] Obarska-Pempkowiak, H. (1996). Seasonal variations in the efficiency of nutrient removal from domestic effluent in a quasi-natural field of reeds (Phragmites communis), in: Etnier, C., Guterstam, B. (Eds.), Ecological Engineering for Wastewater Treatment. CRC Press, Boca Raton, pp. 207-216.

[27] Ocokoljić, M., Milijašević, D., Milanović, A. (2009). Klasifikacija rečnih voda Srbije po stepenu njihove zagađenosti. Zbornik radova - Geografski fakultet Univerziteta u Beogradu, 57, 7-18.

[28] Pavlineri, N., Skoulikidis, N.T., Tsihrintzis, V.A. (2017). Constructed floating wetlands: a review of research, design, operation and management aspects, and data meta-analysis, Chem. Eng. J., 308, 1120-1132.

[29] Prasad, M.N.V., de Oliveira Freitas, H.M. (2003). Metal hyperaccumulation in plants: biodiversity prospecting for phytoremediation technology, Electron. J. Biotechnol., 6(3), pp. 285-321.

[30] Sharma, R., Vymazal, J., Malaviya, P. (2021). Application of floating treatment wetlands for stormwater runoff: A critical review of the recent developments with emphasis on heavy metals and nutrient removal, Sci. Total Environ., 777, 146044.

[31] Shutes, R.B.E. (2001). Artificial wetlands and water quality improvement, Environ. Int., 26(5), 441-447.

[32] Solano, M.L., Soriano, P., Ciria, M.P. (2004). Constructed Wetlands as a Sustainable Solution for Wastewater Treatment in Small Villages, Biosyst. Eng., 87(1), 109-118.

[33] Stewart, F.M., Muholland, T., Cunningham, A.B., Kania, B.G., Osterlund, M.T. (2008). Floating islands as an alternative to constructed wetlands for treatment of excess nutrients from agricultural and municipal wastes - results of laboratory-scale tests, Land Contamination \& Reclamation, 16(1), 25-33.

[34] Stottmeister, U., Wießner, A., Kuschk, P., Kappelmeyer, U., Kästner, M., Bederski, O., Müller, R., Moormann, H. (2003). Effects of plants and microorganisms in constructed wetlands for wastewater treatment, Biotechnol. Adv., 22(1-2), 93-117.

[35] Van de Moortel, A.M.K., Meers, E., De Pauw, N., Tack, F.M.G. (2010). Effects of Vegetation, Season and Temperature on the Removal of Pollut- 
ants in Experimental Floating Treatment Wetlands, Water Air Soil Pollut., 212(1), 281-297.

[36] White, S.A., Cousins, M.M. (2013). Floating treatment wetland aided remediation of nitrogen and phosphorus from simulated stormwater runoff, Ecol. Eng., 61, 207-215.

[37] Xian, Q., Hu, L., Chen, H., Chang, Z., Zou, H. (2010). Removal of nutrients and veterinary antibiotics from swine wastewater by a constructed macrophyte floating bed system, Environ. Manage., 91(12), 2657-2661.

[38] Yang, H., Zhang, Y., Zhang, J. (2021). Artificial Floating Island Technology. IOP Confer. Series: Earth and Environmental Science. 702(1), 012044.
[39] Yang, Z., Zheng, S., Chen, J., Sun, M. (2008). Purification of nitrate-rich agricultural runoff by a hydroponic system, Bioresour. Technol., 99(17), 8049-8053.

[40] Yeh, N., Yeh, P., Chang, Y.-H. (2015). Artificial floating islands for environmental improvement, Renew. Sust. Energ. Rev., 47, 616-622.

[41] Zhou, X., Wang, G. (2010). Nutrient concentration variations during Oenanthe javanica growth and decay in the ecological floating bed system, Res. J. Environ. Sci., 22(11), 1710-1717. 